\title{
German Language for Beginners Applications Based on Mobile Android
}

\author{
S. Alexander, N. Agustinus, and O. Widya
}

\begin{abstract}
According to Deutsch Austauschdinst (DAAD), more than 101 million people in the world speak German and about 20 million people around the world is learning about it. In addition to studying the German language in school or language-courses, it can also be done easily without having to spend a lot of money, simply by using German language learning application based on Android. The application aims to provide knowledge of German language for beginners or at the basic level, Start Deutsch A1 for all ages. The features provided for learning German is equipped with learning materials menu, quizzes menu as exercises and competency test menu which is the simulation test of Start Deutsch A1. To see the development of user capabilities, quizzes are equipped with the assessment contained in the score menu and review answers at the end of each quiz. Based on testing results, this learning application can run well on devices with the Android operating system version 4.1 to 5.0.2, and so is the process of accessing databases on the web services. In addition, the testing is also done by giving questionnaires to 10 respondents to determine the satisfaction's level. Based on questionnaires, $80 \%$ of respondents said they were satisfied with the whole package of applications.
\end{abstract}

Index Terms-German language, learning based application, Mobile Android.

\section{INTRODUCTION}

In simple words, language is a tool to interact or tools to communicate. Languages are used to convey what people think and feel. According to the Dictionary of Indonesian, the language is an arbitrary sound symbol system, which is used by members of a community to work together, interact, and identify themselves [1].

Based on such understanding, mastery of a foreign language other than our mother language is one of the factors for supporting life in this era of globalization. The era where as if each country has no limits, the role of language is growing into the exchange of information between countries on culture, technology, and other fields [2].

In addition to English, German is an important language in international communication. According to Deutscher Austausch Dienst (DAAD), better known by the German Academic Exchange Service, more than 101 million people speaking German and about 20 million learning about it. In

Manuscript received June 7, 2016; revised December 2, 2016.

The authors are with the Informatics Enginerring Department Petra Christian University, Indonesia, Surabaya 60236 (e-mail: alexander@ petra.ac.id,agust@petra.ac.id, widyaongels@yahoo.co.id).
Europe, German is the native language of 100 million people. Not only in Germany, but also in Austria, Switzerland, Luxemburg and Liechtenstein. This puts the German language among the 12 most commonly used language in the world, namely $3.1 \%$ of the world population. In Europe, German is the most widely used naïve languages.

Without having to rely on a course or learn from a book, learning a foreign language can now be done anywhere and anytime with mobile devices that rely on the growing technology, particularly Android operating system. With ease, people who want to learn foreign languages like German can learn on their own or as a self-taught, by accessing the applications that help in learning through their own smartphones.

Therefore, this research proposes an idea of the German language learning applications with the use of Android-based technology that can provide insights into German for beginners or at the basic level (Start Deutsch A1) for all ages. With this application, people who want to learn the German language can learn by themselves, because it uses the Android operating system that allows users to learn anywhere and anytime.

\section{THEORETICAL BASIS}

\section{A. German Language}

German belongs to a group of West German languages and is one family with the Dutch and the English and Scandinavian languages. German is also influenced by Latin, French and lately also by the English language, especially the vocabulary. Although some of the German word borrowed by English (eg Delicatessen, Doppelg ä nger, Kindergaten, Meister), the number of English words borrowed from the German language is large and growing. The example of English words most used are der Airbag, der Jobcentre, shoppen. Some borrowed words have different meanings in German, for example das Handy means cell phones. The borrowed words often referred to as Denglisch (Deutsch + Englisch) [3].

\section{B. Start Deutsch AI}

Start Deutsch A1 (pronounced A ains) is the most basic level certification or for a beginner in German by the Goethe-Institut. Certification exam organized by the Goethe-Institut is already known worldwide and accepted as qualified by various companies and further education institutions in many countries. German language test conducted in accordance with the Goethe-Institut levels refer to the Gemeinsamer europäischer Referenzrahmen für Sprachen (GER) (European Union agreement to offer 
Language Competence), ranging from A1 for beginners to $\mathrm{C} 2$ for most high-level languages [4].

Qualifications required in order to complete the certification level A1:

1) Understand simple questions, notices and phone messages as well as information on the radio about an everyday situation and in brief conversations,

2) Gather the main information from short written messages, advertisements, descriptions, letters and simple newspaper articles,

3) Write brief personal messages,

4) Introduce yourself in a conversation and answer questions about yourself,

5) Ask and reply to simple questions in a conversation on topics affecting you,

6) Make common requests and formulate questions in everyday situations, and reply or respond to these [5].

\section{Android}

Android is an operating system based on Linux Mobile Phone. Android is open source, its source code is free for developers to create applications that can run on Android [6].

\section{MySQL Database}

MySQL is an open source database application program. MySQL is capable of handling large and complex enough databases. MySQL can also handle client server database. MySQL AB makes MySQL as free software licensed under the GNU General Public License (GPL), but also sold under a commercial license for cases where use is incompatible with the GPL. Unlike Apache which is software developed by the general community and the copyright to the source code are owned by their respective authors, MySQL is owned and sponsored by a Swedish commercial company MySQL AB. MySQL AB is holding almost full copyright for all its source code. The man who founded MySQL AB is David Axmark and Allan Larsson came from Sweden, and Michael "Monty" Widenius comes from Finland [7].

\section{SYSTEM ANALYSIS AND DESIGN}

\section{A. System Analysis}

To build a system, it is necessary to analyze the existing system to know the shortcomings. In the analysis of the system, the advantages and disadvantages can be determined by comparing with similar applications. Below are some of the German language learning applications that have been summarized as follows:

1) The Johnny Grammar's Word Challenge is a quiz application for people learning English. This application aims to test the general vocabulary, spelling, and grammar that appeared in the English language daily.

2) Human Japanese is Japanese language learning application, with approaches other than vocabulary and expressions are the discussions, recordings, animations, illustrations, drawings, review and others. On the home page, users are asked to fill in the username and select an avatar, after which it will be given an introduction to the application and its features.

3) Duolingo is learning applications for a variety of languages, including Spanish, French, German,
Portuguese, Italian, Dutch, Irish, Danish, Swedish, and English. This application is provided free of charge and without advertising. On the home page, the user is required to choose the course they want to learn and daily goals with a choice of casual, regular, serious and insane as study duration per day.

4) Learn German - DE Translator is an application for learning the German language, which contains more than 800 German phrases and vocabularies commonly used to tourists and beginners. This application has a parrot that has an excellent clarity accent that sounds very natural with emphasis similar to the original sound and articulation in German which will help in practice the ability to speak and hear.

From the review of some of learning applications above can be compared to the application made, German Language Learning Application for Beginners has advantages in the form of availability of Start Deutsch A1 simulation test in the competency test menu that can help prepare and measure the ability of user on the stage of the Start Deutsch A1. Meanwhile, the disadvantage of German Language Learning Application for Beginners is the mediocre-tend-unattractive display interface.

\section{B. System Design}

The German Language Learning Application system design process consists of two main parts, the web services that provides all the learning data stored in MySQL database and the client part of an Android device that is used to run the application. Learning materials data on Android device are accessible to the web service through the Internet using the HTTP connection. Overall system applications that are made can be seen in Fig. 1.

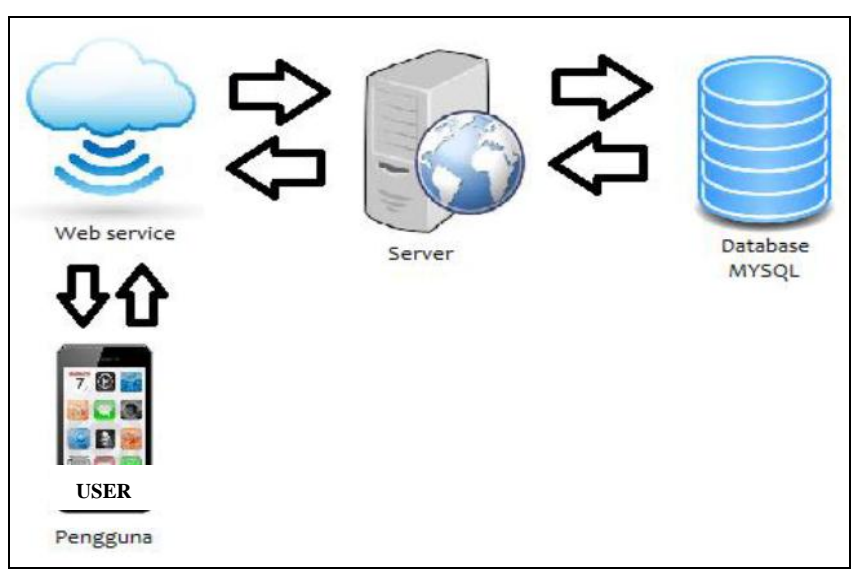

Fig. 1. System application based on Mobile.

\section{Entity Relationship Diagram (ERD) Design}

In Fig. 2 shows the Entity Relationship Diagram (ERD) Design with the physical model of the system. The application system has 17 tables that are linked with other table.

\section{Design Menu}

Design menu to display in the German Language Learning Application accessed by the user can be seen in Fig. 3 .

Menu page consists of 4 options; learning materials menu, quizzes menu, competency test menu, and score board menu. Learning materials consists of 3 categories and each category is composed of several lists (known as submateri) such as 
dialogues and vocabularies, picture dictionaries, grammars, expressions, and social and cultural facts. The quiz menu contains 3 kinds of quizzes: Grammatik, Buchstabieren, and Wörter. Grammatik and Wörter have the same category as the category of learning materials with three possible answers, while Buchstabieren have no category with only two possible answers. The competency Test menu contains Start Deutsch A1 model exercises. Score Board is divided into 2: Score board for quizzes and for competency test. Each featuring top 10 best scores.

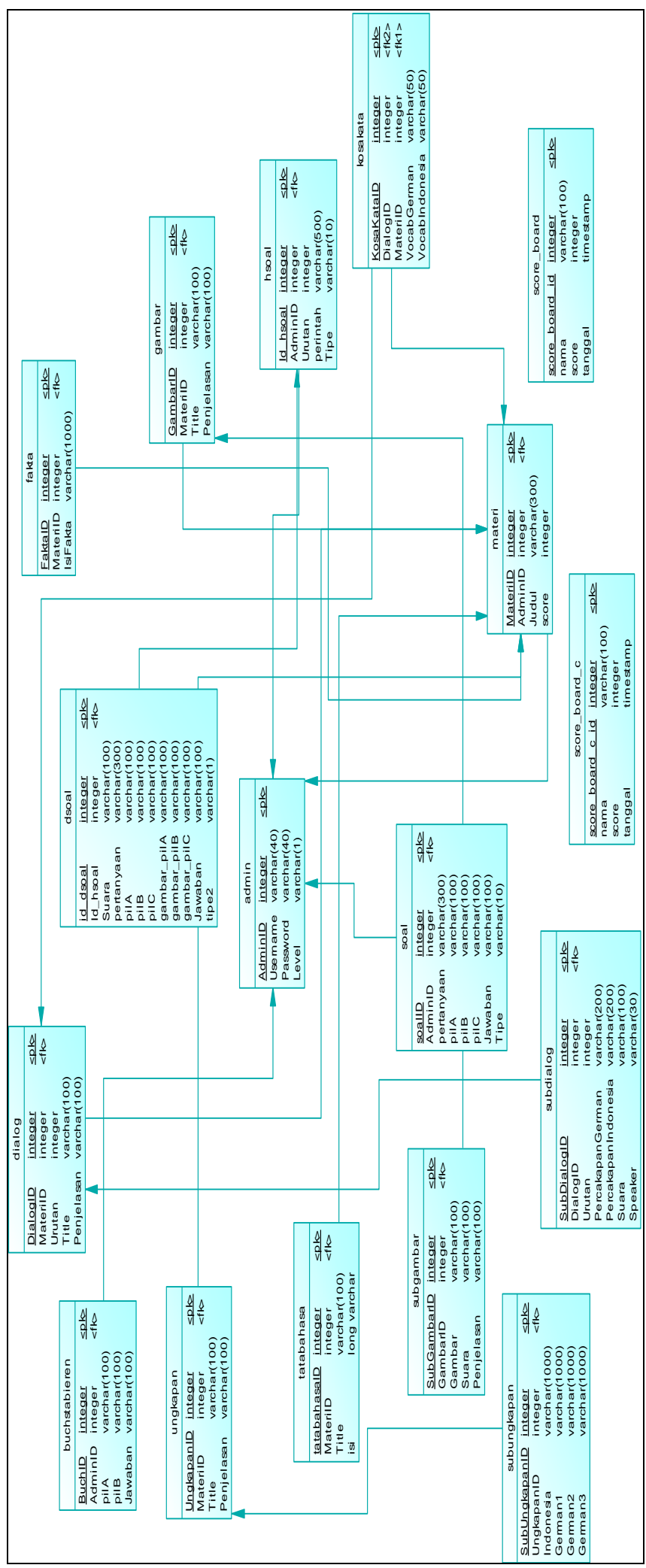

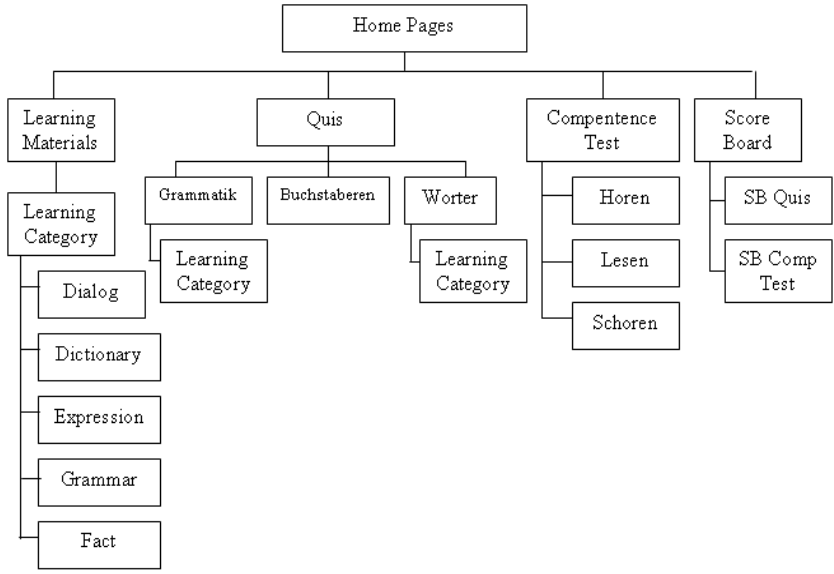

Fig. 3. Design menu.

\section{System TESTING}

The system testing carried out by using several Android devices, including LG G3, Samsung Galaxy Grand I9082 and Samsung Galaxy Tab 3 7.0. Based on the testing of the three devices mentioned, found similarities in the appearance of the application with different operating systems. Web service functions run smoothly in learning materials, quiz, test competence, and score board data access. Accessing web service requires internet connection, therefore a device that is used must have an internet connection. Fast or slow data retrieval depends on the internet connection for each device.

The menu page is the first page that appears after the splash screen. On the menu page, there are 4 buttons that contain learning materials menu, quizzes menu, competency test menu, and score board menu. Testing learning materials page can be seen in Fig. 4 and sub materials list view can be seen in Fig. 5.

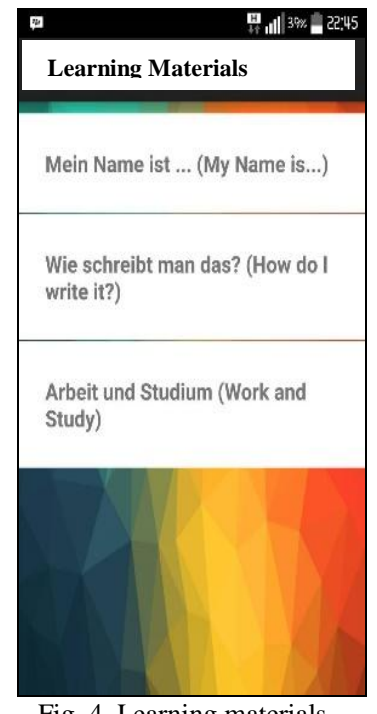

Fig. 4. Learning materials.

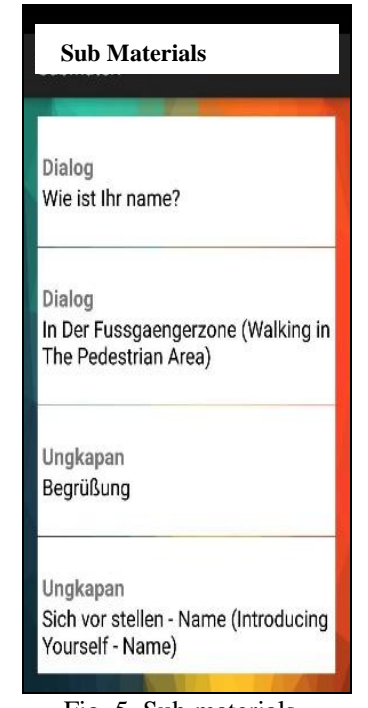

Fig. 5. Sub materials.
Dialogue and vocabulary pages are 2 different pages that merge into one, because the vocabulary page can only be accessed through dialogue page by pressing the vocabulary button at the top of the page. Another reason why dialogue and vocabulary page are connected is because of the words that exist in the vocabulary is taken from a conversation of dialogue. Dialogue page testing is performed by testing 
whether the sound will be heard if you press a part of the dialogue.

Picture dictionary as the name implies, contains dictionaries, but is displayed in the form of images and sound. Picture dictionary page testing is done by checking whether the voice can be heard and whether the images on the database server can be displayed.

Expression page contains expressions that are often encountered (maximum 3 expressions) in the German language and meaning in Indonesian.

Grammar page contains grammar that has been summarized for each category of material in order to allow user to find and learn.

The form of a social and cultural page isn't much different from the grammar page, because both pages using WebView and data can be entered as plain text or in HTML.

Quiz page consists of 3 types of quizzes, Grammatik (about grammar, where user will be asked to fill in the blanks of a sentence or a dialog with three possible answers), Wörter (about the writing / spelling of the word, which user will be asked to choose from two options), and Buchstabieren (about the words that are usually used in a given situation, the user will be asked to fill in the blanks of a sentence or a dialog with three possible answers). The quizzes have a maximum of 15 seconds to choose the correct answer. Here can be seen Grammatik and Worter page view in Fig. 6, Buchstabieren page view in Fig. 7, and the quiz result in Fig. 8.

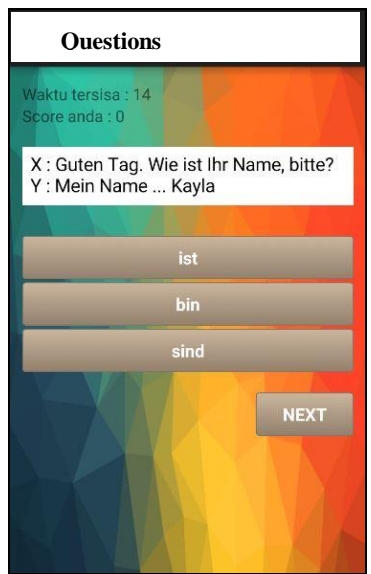

Fig. 6. Grammatik and Wörter.

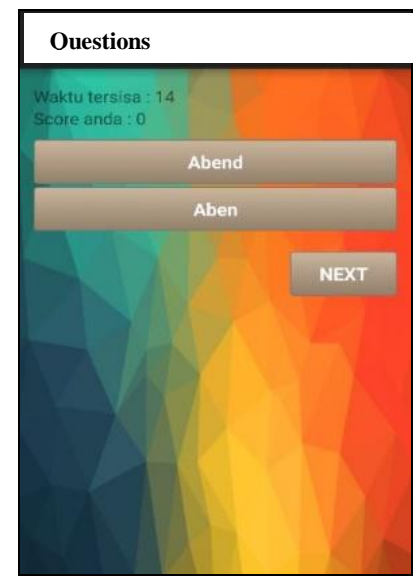

Fig. 7. Buchstabieren.

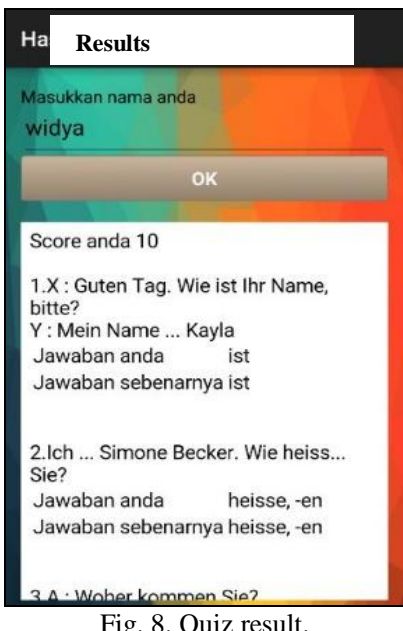

Competency test page is the page that contains the Start
Deutsch A1 simulation test which consists of three categories that appear in sequence, namely Hören (listening), Lesen (reading), and Schreiben (writing). Hören and Lesen consists of 3 teil (part) while Schreiben only consists of 1 section. When will move to the next categories or sections, the divider page will be displayed. The divider page can be seen in Fig. 9. Especially for Hören section, the play button to play the sound will be displayed. Competency test page can be seen in Fig. 10, and test result page can be seen in Fig. 11.

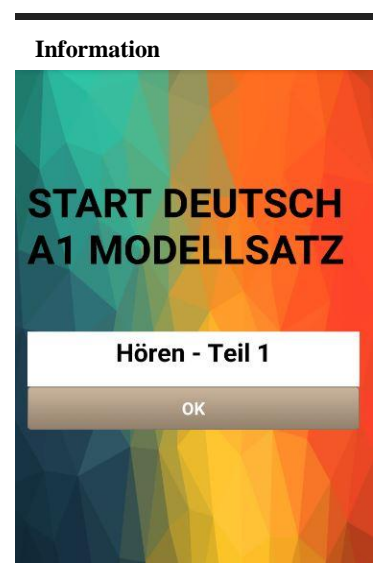

Fig. 9. Divider page.

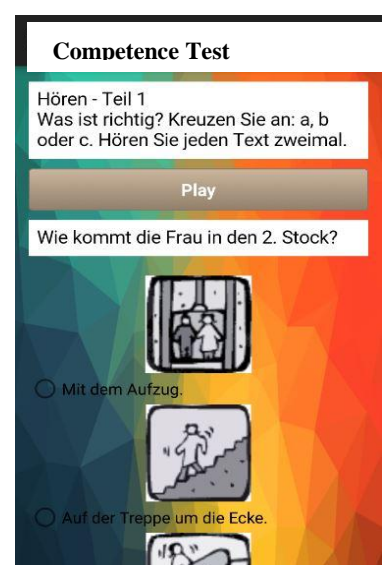

Fig. 10. Competency test.

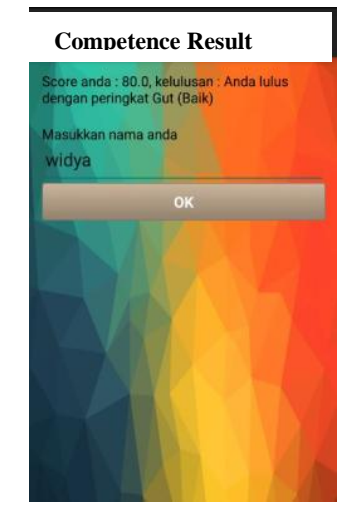

Fig. 11. Competency test result.

In Fig. 11 score Board is divided into 2, score board for quizzes and for competency test. Each featuring top 10 best scores and user name.

\section{CONCLUSIONS AND SUGGESTIONS}

\section{A. Conclusions}

Based on the test results we can conclude the following:

- The features contained in the German Language Learning Application for Beginners consists of learning materials, quizzes, examination test, and score board.

- This application is accessible online by using internet and web services, since all data is stored in the database server.

- Based on test results and the distribution of questionnaires, $80 \%$ of respondents stated that the application is useful, but it still has its drawbacks on the mediocre-tend-unattractive display interface.

\section{B. Suggestions}

- Interface design needs more attention to make it more attractive 


\section{REFERENCES}

[1] Badan Pengembangan dan Pembinaan Bahasa, Kemdikbud (Pusat Bahasa), n.d.. Kamus Besar Bahasa Indonesia (KBBI).

[2] Purwati, Mudah dan Praktis Bahasa Jerman, Yogyakarta: Penerbit Pustaka Widayatama, 2006.

[3] P. Coggle and H. Schenke, Complete German 1, Jakarta: Kesaint Blanc. 2012.

[4] N. Adi, Bahasa Jerman Sehari-hari, Jakarta: Penerbit Kesaintblanc, 2010 .

[5] Balabel, Cara Mudah Menguasai Bahasa Jerman, Jakarta: PT. Suka Buku, 2009.

[6] S. Nazruddin, Pemrograman Aplikasi Mobile Smartphone dan Tablet PC Berbasis Android,Bandung: Penerbit Informatika, 2011.

[7] P. Kasiman, Aplikasi Web Dengan PHP dan MySQL, Yogyakarta: Penerbit Andi Offset, 2006.

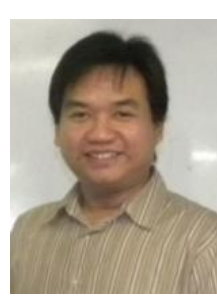

Alexander Setiawan Obtained his bachelor computer degree in informatics engineering from Petra Christian University, Surabaya, Indonesia in 2003. He received his master in information technology from Gadjah Mada University, Yogyakarta, Indonesia, in 2008. Now, he served as Assistant Professor and a lecturer in the Department of Informatics Engineering at Petra Christian University, Surabaya, Indonesia. His primary research interests are in software engineering, business intelligent, management information system, and human computer interaction.

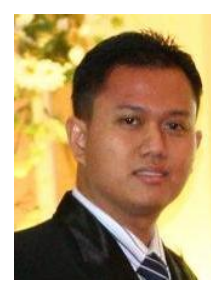

Agustinus Noertjahyana Obtained his bachelor computer degree in informatics engineering from Institute of Applied Science and Technology Surabaya, Indonesia in 2001. He received his master in magister management technology from Sepuluh Nopember Institute of Technology Surabaya, Indonesia, in 2005. Now, he served as Assistant Professor and a lecturer in the Department of Informatics Engineering at Petra Christian University, Surabaya, Indonesia. His primary research interests are in networking, mobile computing and human computer interaction. 